\title{
Development of Interactive Digital Module in Individual Counseling Courses
}

\author{
Miswanto $^{1}$ Abdul Munir ${ }^{2}$ Nurarjani $^{3}$ \\ ${ }^{1,2,3}$ Guidance and Counseling Department, Faculty of Education, Universitas Negeri Medan, Indonesia. \\ *Corresponding author.Email: miswanto@unimed.ac.id, abdulmunir@unimed.ac.id,nurajani@unimed.ac.id
}

\begin{abstract}
The learning process in the network (Online) has many problems, one of which is that students do not have standardized interactive digital-based modules in individual counseling courses. This study aims to formulate and design interactive digital modules in appropriate individual counseling courses and to describe the level of use of interactive digital modules by students of the 2019 batch of Guidance and Counseling Faculty of Education, Universitas Negeri Medan S1 Study Programs. The method used is Research and Development (RnD) with the Analyze, Design, Development, Implementation, Evaluation (ADDIE) model. The feasibility test was carried out by two material experts and two media experts and the usability test was carried out by twenty-two students of the 2019 batch of S-1 Guidance and Counseling Faculty of Education, Universitas Negeri Medan Study Program and Focus Group Discussion by three individual counseling lecturers. The instruments used are the Scale and Focus Group Discussion. Data were analyzed descriptively. Based on the research results, in general it can be concluded that the interactive digital module is feasible and can be used by students of the S-1 Guidance and Counseling Faculty of Education, Universitas Negeri Medan Study Program in individual counseling courses.
\end{abstract}

Keywords: Interactive Digital Module, Individual Counseling.

\section{INTRODUCTION}

Education is needed by every human being in his life. Therefore, humans must get the right to education as well as possible. So that these humans become individuals who are knowledgeable, capable, creative, and independent. This is explained by [1] Law Number 20 of 2003 concerning the National Education System Article 3 that the purpose of national education is to develop the potential of students to become human beings who believe and fear God Almighty, have noble character, are healthy, knowledgeable, capable, creative, independent, and become a democratic and responsible citizen.

The educational objectives are achieved through the learning process in face-to-face classes and virtual classes (online). During this Covid-19 Pandemic, educators (lecturers) in the virtual class (online) learning process must have teaching materials. One of the teaching materials is an interactive digital module. Using interactive digital modules can make students not feel bored or bored and these students have creativity and independence in learning. This can also increase the effectiveness of students in learning because there is an encouragement of motivation in learning and innovation in delivering learning materials.

By utilizing interactive digital modules, educators (lecturers) in delivering learning materials in virtual classes (online) can make the learning atmosphere more innovative, interesting and more enjoyable, helping to smoothen and achieve a learning goal. This interactive emodule is supported by [2] Government Regulation of the Republic of Indonesia Number 19 Article 19 [1] of 2005 concerning National Education Standards which states that learning in schools is carried out interactively, inspiring, fun, challenging, motivating students to participate actively.

[3] Explained that interactive e-modules allow students not only to involve the senses of hearing, but also sight. The more senses that are used to receive information, the more likely that information is remembered and understood. Experts prove that there are significant differences in learning outcomes obtained through the senses of sight and hearing.

Based on the problems that occurred, researchers were interested in developing teaching materials in the 
form of interactive digital modules so that they could be used by Guidance and Counseling students in individual counseling courses. This is because using interactive digital modules can increase students' motivation, creativity, and independence in the learning process, in this case students can do their own learning activities without the direct presence of educators (lecturers). This is in line with the results of research by [4] showing that the use of interactive emodules as learning media is categorized as very good with an average score of $84.72 \%$. The results of student responses also showed that all aspects of the questionnaire were categorized as very good, so the interactive e-module was appropriate to be used as a learning medium in the learning process. [5] Showed that interactive e-modules were useful as a learning medium. Based on the theoretical review, several advantages and disadvantages of using interactive e-modules will be presented as a learning medium in the digital era of this century.

Based on the research results of [6] also show that the design of interactive e-modules that have been developed in digital simulation subjects using innovative projectbased learning models are successfully implemented and feasible to be implemented in the learning process.

Furthermore, the results of observations made by researchers, most students who take individual counseling courses do not have a theory book in which there is material containing writing accompanied by charts. Whereas competency standards in the curriculum require students to understand concepts and be fluent in individual counseling courses.

Based on the description above, the problem that arises is that students who take individual counseling courses do not have modules. From these problems,
Program Faculty of Education, State University of Medan.

\section{METHOD}

This research is a development research method that aims to develop or validate products used in education and learning. Based on the characteristics of several existing development models, the researcher chose the ADDIE model (Analyze, Design, Development, Implementation, and Evaluation) as a reference in this study. According to [7] the process of developing the ADDIE model is as follows.

The trial subjects in this study consisted of experts in the field of individual counseling and media consisting of two material experts and two media experts to conduct a feasibility test on the product and twenty-two students of the 2019 batch of S-1 Guidance and Counseling Faculty of Education, Universitas Negeri Medan Study Program to assess the usability test. of the designed product. Collecting data in this study using a scale and through Focus Group Discussion. The data collected is then processed descriptively to describe the characteristics of the distribution of scores of each respondent by determining the category of product trial results.

\section{RESULTS AND DISCUSSION}

\subsection{Research Result}

In this section, the presentation of development data and discussion is presented. After the research product in the form of digital-based modules in individual counseling courses has been compiled, then proceed with trials to material experts in the field of counseling to see the feasibility of the content/construct of the modules and media experts developed.

Table 1. Test Results to Material Experts

\begin{tabular}{|c|c|c|c|c|c|c|}
\hline \multirow[t]{2}{*}{ No } & \multirow[t]{2}{*}{ Aspect } & \multicolumn{2}{|c|}{ Material Expert Score } & \multirow[t]{2}{*}{$\Sigma$} & \multirow[t]{2}{*}{ Average } & \multirow[t]{2}{*}{ Category } \\
\hline & & A & $\mathrm{B}$ & & & \\
\hline 1 & Appearance and attractiveness & 18 & 18 & 36 & 3.60 & Feasible \\
\hline 2 & Reference framework & 12 & 11 & 23 & 3.83 & Feasible \\
\hline \multirow[t]{2}{*}{3} & Mapping of objectives & & & & & \\
\hline & and indicators & 14 & 16 & 30 & 3.75 & Feasible \\
\hline 4 & Module Contents & 35 & 45 & 80 & 4.44 & Very Feasible \\
\hline 5 & Topic presented & 46 & 52 & 98 & 4.45 & Very Feasible \\
\hline \multirow[t]{3}{*}{6} & Language Usage & 16 & 18 & 34 & 4.25 & Very Feasible \\
\hline & Amount & 141 & 160 & 301 & 4.18 & Feasible \\
\hline & Average & 3.92 & 4.44 & 8.36 & & \\
\hline
\end{tabular}

researchers are interested in researching "Development of Interactive Digital Modules in Individual Counseling Courses. Researchers want to formulate and design interactive digital modules in appropriate individual counseling courses and describe the level of use by 2019 students of the Guidance and Counseling S-1 Study
The following table presents the results of testing research products to experts regarding the assessment of digital-based modules in the developed individual counseling courses.

Based on the table above, it can be seen that the overall average score is 4.18 , which means that the overall interactive digital-based individual counseling 
module that is prepared materially is in the appropriate category. Thus, the assessment provided by the experts on the interactive digital-based individual counseling module developed in content is appropriate for use by students of the guidance and counseling study program when taking individual counseling courses.

In an open questionnaire for comments and suggestions from the two experts on the entire interactive digital-based individual counseling module compiled as a research product, it can be concluded that the two experts gave positive comments and suggestions regarding mapping the objectives and learning indicators in the appropriate module were further clarified and simplified. grammar in the module. Furthermore, the interactive digital-based individual counseling module that has been compiled is validated by media experts.
Furthermore, an interactive digital-based individual counseling module that has been compiled and validated by material experts and media experts is used as the basis for conducting trials for students to see the usability of the product.

Based on the Table 3, it can be seen that the overall average score is 4.03 , which means that the overall results of student trials on interactive digital-based individual counseling modules are in the high category. In an open questionnaire containing comments and suggestions from students on the overall research product, they gave positive comments and the suggestions given needed to simplify the language and use of words in the module. Furthermore, the images in the module should be adapted to the discussion. Based on the test results of material experts, media experts and product usability tests, the

Table 2. Test Results to Media Experts

\begin{tabular}{|c|c|c|c|c|c|c|}
\hline \multirow[t]{2}{*}{ No } & \multirow[t]{2}{*}{ Aspect } & \multicolumn{2}{|c|}{ Media Expert Score } & \multirow[t]{2}{*}{$\sum$} & \multirow[t]{2}{*}{ Average } & \multirow[t]{2}{*}{ Category } \\
\hline & & $\mathrm{A}$ & $\mathrm{B}$ & & & \\
\hline 1 & Software engineering & 26 & 24 & 50 & 4.17 & Feasible \\
\hline 2 & Learning Design & 53 & 50 & 103 & 3.68 & Feasible \\
\hline \multirow[t]{3}{*}{3} & Visual Communication & 29 & 30 & 59 & 4.21 & Very Feasible \\
\hline & Amount & 108 & 104 & 212 & 3.93 & Feasible \\
\hline & Average & 4 & 3.85 & 7.85 & & \\
\hline
\end{tabular}

Based on the Table 2, it can be seen that the overall average score is 3.93 , which means that the overall interactive digital-based individual counseling module arranged in media is in the appropriate category. Thus, the assessment given by the experts to the interactive digital-based individual counseling module developed by media is suitable for use by students of the guidance and counseling study program when taking individual counseling courses.

In an open questionnaire for comments and suggestions from the two experts on the entire interactive digital-based individual counseling module compiled as a research product, it can be concluded that the two experts gave positive comments and suggestions regarding visuals and learning videos in the module to be designed to be more interesting in order to improve student learning motivation, especially in individual counseling courses.

Table 3. Appropriateness Test Results to Students

\begin{tabular}{|c|c|c|c|c|}
\hline \multirow[t]{2}{*}{ No } & \multirow{2}{*}{ Aspect } & \multicolumn{2}{|c|}{ Student Validation Score $(\mathrm{N}=22)$} & \multirow[t]{2}{*}{ Category } \\
\hline & & $\sum$ Average & & \\
\hline 1 & Planning & 274 & 4.15 & High \\
\hline 2 & Implementation & 513 & 3.89 & High \\
\hline \multirow[t]{3}{*}{3} & Evaluation & 367 & 4.17 & High \\
\hline & Amount & 1154 & 4.03 & High \\
\hline & & Average & 88.77 & \\
\hline
\end{tabular}

research product can be said to be ready for an interactive digital-based individual counseling module assessment by the Guidance and Counseling Lecturer who is in charge of individual counseling courses after making improvements and revisions to the module based on input and suggestions. material experts and media experts as well as students.

\section{Focus Group Discussion (FGD) Results for Interactive Digital Module Assessment}

In the FGD activities held, each participant was asked to provide an opinion on the entire research product, namely an interactive digital module in individual counseling courses. The FGD was held through.

Based on the results of the FGD, it was found that the use of interactive digital modules in individual counseling courses showed positive things to be immediately implemented in the learning process of individual counseling courses. 
Table 4. FGD Results for Interactive Digital Module Assessment

\begin{tabular}{|c|c|c|c|c|c|c|c|}
\hline \multirow[t]{2}{*}{ No } & \multirow[t]{2}{*}{ Aspect } & \multicolumn{3}{|c|}{ BK Lecturer Score } & \multirow[t]{2}{*}{$\sum$} & \multirow{2}{*}{\multicolumn{2}{|c|}{ Average Category }} \\
\hline & & $\mathrm{A}$ & $\mathrm{B}$ & $\mathrm{C}$ & & & \\
\hline 1 & Description & 4 & 4 & 3 & 11 & 3.67 & High \\
\hline 2 & Aim & 4 & 4 & 4 & 12 & 4 & High \\
\hline 3 & Use of digital modules & 5 & 4 & 5 & 14 & 4.67 & Very high \\
\hline 4 & Digital module topics & 4 & 4 & 4 & 12 & 4 & High \\
\hline 5 & Media & 4 & 3 & 4 & 11 & 3.67 & High \\
\hline 6 & Summary & 4 & 4 & 4 & 12 & 4 & High \\
\hline 7 & Assignment sheet & 4 & 4 & 4 & 12 & 4 & High \\
\hline 8 & Evaluation & 3 & 4 & 3 & 10 & 3.33 & High enough \\
\hline 9 & Closing & 5 & 4 & 5 & 14 & 4.67 & Very high \\
\hline 10 & Grammar & 5 & 4 & 5 & 14 & 4.67 & Very high \\
\hline \multirow[t]{2}{*}{11} & Readability and easy & & & & & & \\
\hline & to understand & 4 & 4 & 4 & 12 & 4 & High \\
\hline \multirow[t]{3}{*}{12} & Digital module application & 4 & 4 & 4 & 12 & 4 & High \\
\hline & Amount & 50 & 47 & 49 & 146 & 4.06 & High \\
\hline & Average & 4.17 & 3.92 & 4.08 & 12.17 & & \\
\hline
\end{tabular}

Based on the FGD process at the evaluation stage, it was found that the overall assessment given by FGD participants to interactive digital modules in individual counseling courses was in the high category with an average score of 4.06. This means that the fgd participants gave a positive assessment of the presence of interactive digital modules in individual counseling courses as a medium and source of reference in individual counseling courses and are ready to be used in the learning process of individual counseling courses on campus.

\subsection{Discussion}

Based on the description and analysis of the data from previous research, the following discussion of the research findings is presented as follows.

\subsubsection{Eligibility Level of Interactive Digital- Based Individual Counseling Module}

The research products produced in this study include interactive digital-based individual counseling modules. This product is named "Digital Based Approach Module (Individual Counseling Theory and Application)".

In implementing this product development, the researcher guided the steps contained in the ADDIE model, namely analyze, design, development, implementation, and evaluation. From the results presented in the development stage, it is known that the modules compiled have reached the appropriate criteria by material experts and media experts. This is evidenced by the overall average value of material experts at 4.18 in the appropriate category and the overall average value of media experts at 3.93 in the appropriate category. The feasibility value given by these experts is a value based on objectivity to the content and media contained in the module.

The assessment given by the material expert is related to six aspects, namely appearance and attractiveness, terms of reference, mapping of objectives and indicators, module content, topics presented, and language use. Furthermore, the assessment given by media experts is related to three aspects, namely software engineering, learning design, and visual communication. From the material and media aspect, nothing shows an assessment that is below the eligibility standard. This further strengthens that the interactive digital-based individual counseling module is feasible to be used by students and can be a reference when attending lectures on individual counseling courses. Based on [8] the use of the module aims to achieve educational goals effectively and efficiently. Furthermore, [9] research results show that the research product in the form of a BK module for bullying prevention in schools is declared content-worthy and can be used by BK teachers in an effort to prevent bullying in schools at the high school level. In line with [10] in the results of the study showed that the computerbased bilingual learning module on the subject of word processing software for fourth grade elementary school students that was developed had met the valid and practical categories for use by both students and teachers.

\subsubsection{Level of Use of Interactive Digital-Based Individual Counseling Module}

The research findings in order to determine the level of usability of the product illustrate that the interactive digital-based individual counseling module has a high level of use by students of the 2019 batch of BK FIP UNIMED S-1 Study Program. The facts described above are supported by the product usability assessment, which is 4.03 in the high category. This means that the interactive digital-based individual counseling module can be used by students when taking individual counseling courses.

Furthermore, the assessments given by students related to three aspects, namely planning, implementation, and evaluation, none of which showed an assessment that was below the usability standard. 
In general, the interactive digital-based individual counseling modules that have been compiled have reached an adequate level of usability. For the planning aspect, students can do it well. All tools needed to use the module can be provided by students. Furthermore, the implementation aspect shows that students can follow the steps that have been prepared. Next, the evaluation aspect used was able to see student gains after attending lectures on individual counseling courses. This is in line with the results of research by [11] which shows that the implementation of the guidance and counseling module to improve students' interpersonal communication skills that have been compiled has reached an adequate level of usability. Rayandra [11] explains that by using the module students can learn at their own pace and learn more independently. This is in accordance with the opinion of [12] which explains that the module contains an independent learning package which contains materials, methods, and ways of evaluating which are designed systematically and attractively to achieve the expected learning objectives.

Thus, the research product in the form of an interactive digital-based individual counseling module can be used by students of the 2019 batch of S-1 BK FIP UNIMED Study Program when taking individual counseling courses.

\section{CONCLUSION}

Based on the results and discussion, it can be concluded that the interactive digital-based individual counseling module is in the appropriate category by material and media experts. This means that the experts agree that the modules that have been compiled are suitable for use by students when taking individual counseling courses. Furthermore, the level of use of interactive digital-based individual counseling modules by students is in the high category. This means that the interactive digital-based individual counseling module can be used as a learning medium and reference in individual counseling courses.

\section{REFERENCES}

[1] Undang-undang Nomor 20 tahun 2003 tentang Sistem Pendidikan Nasional. Jakarta: Depdiknas RI.

[2] Peraturan Pemerintah Nomor 19 tahun 2005 tentang Standar Nasional Pendidikan. Jakarta: Departemen Pendidikan Nasional.

[3] Arsyad A. (2014). Media Pembelajaran. Jakarta: Rajagrafindo.

[4] Imansari, N., and Sunaryantiningsih, I. (2017). Pengaruh Penggunaan E-Modul Interaktif terhadap Hasil Belajar Mahasiswa pada Materi Kesehatan dan Keselamatan Kerja. Jurnal Ilmiah Pendidikan
Teknik Elektro. $2 \quad$ (1). 11-16. http://dx.doi.org/10.30870/volt.v2i1.1478.

[5] Lidia A. H., Siswandari, \& Harini. (2019). Pengembangan E-Modul Interaktif Sebagai Media Pembelajaran di Era Digital. Prosiding Seminar Nasional Teknologi Pendidikan Pascasarjana UNIMED. 298-305.

[6] Komang, R.W., Naswan, S., \& Ketut, A. (2018). Pengembangan E-Modul Interaktif Berbasis Proyek Mata Pelajaran Simulasi Digital. Jurnal Pendidikan Teknologi dan Kejuruan. 15(2), 188-199. https://doi.org/10.23887/jtpi.v8i1.2238.

[7] Molenda, M. 2003. "In Search of the Elusive ADDIE Model". JurnalPerformance Improvement, 42 (3): 34-36.

[8] Sudjana, N. \& Rivai, A. (2001). Teknologi Pengajaran. Bandung: Sinar Baru Algensindo.

[9] Hengki, Y., Daharnis, \& Herman, N., (2013). Pengembangan Modul Bimbingan dan Konseling untuk Pencegahan Bullying di Sekolah. Jurnal Ilmiah Konseling. 2(1), 98-106. DOI : https://doi.org/10.24036/0201321866-0-00.

[10] Adlia, A. (2015). Pengembangan dan Analisis Validasi Modul Pembelajaran Bilingual Berbasis Komputer Pada Pokok Bahasan Perangkat Lunak Pengolah Kata Untuk Siswa Kelas IV Sekolah Dasar. Jurnal Edik Informatika. 2(i1). 19.https://doi.org/10.22202/ei.2015.v2i1.1434.

[11] Jumadi, M., S., T., Mudjiran, \& Herman, N. (2016). Pengembangan Modul Bimbingan dan Konseling untuk Meningkatkan Kemampuan Komunikasi Interpersonal Siswa. Jurnal Ilmiah Konseling. 5(3). 135-139. DOI https://doi.org/10.24036/02016536493-0-00.

[12] Mulyasa, E. 2005. Kurikulum Berbasis Kompetensi: Konsep, karakteristik, dan implementasi.Bandung: RemajaRosdakarya. 